\title{
Spatial distribution of halophytes in the Mondego salt marsh and plant responses to environmental conditions
}

\author{
Paula Castro, Helena Freitas
}

\author{
Centre for Functional Ecology, Department of Life Sciences, \\ University of Coimbra, PO BOX 3046, 3001-401 Coimbra, Portugal \\ e-mail: pcastro@ci.uc.pt
}

\begin{abstract}
Summary. We propose to analyze the spatial distribution of halophytes in the salt marsh of the Mondego estuary in order to understand how environmental conditions affect their distribution patterns. Furthermore we discuss the responses of these species to human activities in this ecosystem and the consequent increase in nutrient loading.
\end{abstract}

Key words: Mondego estuary, salt marsh, halophytes, anthropogenic impacts.

\section{Introduction}

Salt marshes are found fringing in many of the world's coastal areas coasts, occupying the interface between land and sea. They are natural or semi-natural areas, vegetated by halophytic species (herbs, grasses or small shrubs), bordering saline water bodies, and subjected to periodic flooding as a result of tidal fluctuation (Beeftink 1977). The characteristic floristic composition and structure of salt marsh areas is sufficient to distinguish them from the surrounding areas. Monitoring salt marshes is critical to understand their dynamics and to ensure the effective management of these ecosystems. Despite the very long history of salt marsh studies, reliable data on salt marsh area are not available in Europe (Allen 2000).

In this study, we aim to characterize the spatial distribution of the most abundant halophytes in the Mondego estuary, in the centre of Portugal. Additionally, we discuss plant responses to anthropogenic disturbance and nutrient loading. Salt marsh plants are important biological agents that control sediment redox structure, nutrient cycling and the degree of eutrophication, linking the nutrients in sediments with the overlaying water (Sousa et al. 2008).

\section{Methods}

We compiled results from several studies conducted in the Mondego estuary located in the centre of Portugal, between $40^{\circ} 08^{\prime} \mathrm{N}$ and $8^{\circ} 50^{\prime} \mathrm{W}$ (Fig. 1). Current spatial distribution of halophytes in this salt marsh was analysed in the field, and, in addition, aerial photographs were used to analyse marsh evolution from 1945 to 1998.

Near the mouth, the river is divided in two arms with distinct sedimentology and hydrodynamic characteristics. The north arm has a maximum depth of $8 \mathrm{~m}$ and is a frequently used navigation channel. The south arm is shallower with maximum depth of $4 \mathrm{~m}$ and largely silted-up in the upstream areas. Consequently, the circulation in this arm depends mainly on tides and small freshwater inputs of the Pranto River, a tributary of the Mondego River. Salt marsh habitats are found in both arms with larger spots detected in the south arm near the Cinco Irmãos bifurcation.

We also analysed nutrient content and $\delta^{15} \mathrm{~N}$ values in leaves of three dominant plant species: Spartina maritima, Halimione portulacoides, and Zostera noltii. Vertical profiles of $\mathrm{N}, \delta^{15} \mathrm{~N}$ and $\mathrm{Pb}$ were measured in sediments as markers that convey notions as to the relative influence of 


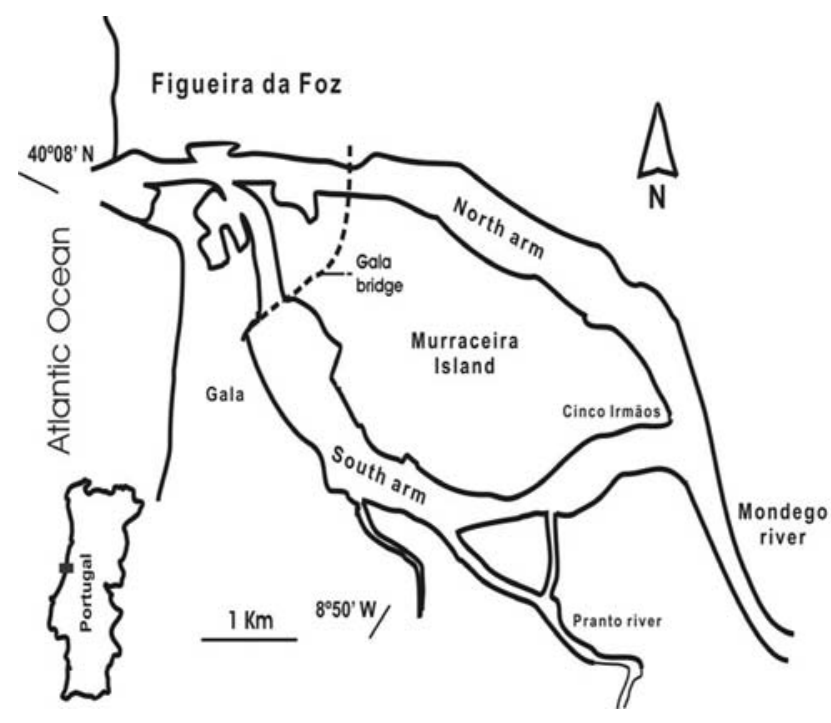

Figure 1. Location map of the Mondego estuary

anthropogenic influence over the past decades. Leaf fall patterns and $\mathrm{N}$ tissue distribution in S. maritima are presented as well.

\section{Results and discussion}

The most dominant plant species in this salt marsh are Halimione portulacoides and Spartina maritima. In the lower marsh an important bioindicator, Zostera noltii, is present. Other taxa, such as Atriplex, Beta, Sonchus, Suaeda, Juncus, Salsola are also common. Sarcocornia sp. and Salicornia sp. are present in more saline soils.

To cope with environmental conditions such as salinity, flood, and nutrient availability, plants develop some physiological, biochemical and anatomical mechanisms to regulate the osmotic potential of tissues, the internal salt content and to facilitate adaptation to anaerobic soil conditions. For example, Spartina maritima is capable of adjusting $\mathrm{N}$ tissue distribution when growing in low $\mathrm{N}$ conditions (summer) and also before leaf fall in order to avoid the waste of $\mathrm{N}$ and energy, indispensable for plant survival. Leaf fall is highly seasonal, being significantly higher during dry months.

The conversion of the salt marsh into non-tidal land has a very long history in this region. Embanking these areas to create agricultural land occurs since early times for several agricultural practices and in 1947 most of the area was transformed for these activities as well as for salt extraction and aquaculture. Long-term changes in the Mondego estuary revealed a reduction in the salt marsh area after 1958 in almost $20 \%$ and an increase in the concentration of $\mathrm{Pb}, \mathrm{N}$, and $\delta^{15} \mathrm{~N}$ in the sediment were clearly related to the progressive increase of human pressure near the estuarine area.

Plants can also act as important indicators of anthropogenic influence. For instance, our studies showed that $\mathrm{N}$ isotopic signatures in leaves of $S$. maritima, $H$. portulacoides, and Z . noltii leaves can be useful indicators of land-derived nitrogen in estuaries.

\section{References}

Allen J. R. L., 2000, Morphodynamics of Holocene salt marshes: a review sketch from the Atlantic and Southern North Sea coasts of Europe, Quaternary Sci. Rev. 19: 1155-1231.

Beeftink W. G., 1977, The coastal salt marshes of western and northern Europe: an ecological and phytosociological approach, [in:] V. J. Chapman (ed.) Ecosystems of the World, Elsevier Scientific Pub. Co., New York.

Sousa A. I., Lillebø A. I., Caçador I. \& Pardal M. A., 2008, Contribution of Spartina maritima to the reduction of eutrophication in estuarine systems, Environ. Pollut. 156: 628-635. 